\title{
Analysis Of Traffic Accident Area On The Road In Gresik District Based On Geographic Information System
}

\author{
Mohammad Wildan Choirul Umam*, Farida Hardaningrum, Ronny Durrotun Nasihien \\ Department of Civil Engineering, Faculty of Engineering, Narotama University, Indonesia \\ *Corresponding author e-mail: mohwildan93@gmail.com
}

Manuscript received 23 Feb 2021; revised 2 March. 2021; accepted 15 March 2021. Date of publication 2 April 2021

\begin{abstract}
Gresik regency as the population increases and people use roads for their activities, accidents often occur on roads, especially in Manyar sub-district, which also has many industrial places. According to accident data for the last 4 years from the police, it was found that there was an increase and decrease in the number of accident events each year. This study uses secondary data from the local police. Then the data is analyzed using the EAN (Equivalent Accident Number), UCL (Upper Control Limit), BKA (Upper Control Limit) method, and using QGIS software to display in more detail the accident-prone areas. The results of the analysis using the EAN method obtained the highest number of accidents on J1. Raya Manyar KM 10 is 604. For the BKA value of 384, while the UCL value is 374, from these results that the EAN value at JL Raya Manyar KM 10 exceeds the BKA and UCL values, it can be concluded that Jl. Raya Manyar KM 10 is an accident-prone area. The results of the analysis are then entered into the QGIS software to display in more detail the areas prone to traffic accidents on roads in Manyar District, Gresik.
\end{abstract}

Keywords: roads, traffic accident prone areas, geographic information systems.

\section{Introduction}

Transportation is a very important part of human life, especially for accelerating development and running the wheels of equitable economic growth in various regions, especially for the land transportation system. The available facilities and infrastructure help people to travel to a place. Gresik Regency as a regency with high economic growth and large population growth, many people use the road and indirectly cause problems with the risk of congestion and traffic accidents, especially on collector roads in Manyar District which are considered prone to traffic accidents, then research is needed to analyze accident-prone areas [1].

The Geographic Information System based software is used to process accident data and can present information on accident-prone areas. So that policyholders and authorities can see and anticipate accident-prone points on roads quickly and accurately [2].

Based on the background in the description above, the formulation of the selected problem is:

1. Where is the location of the road that is prone to traffic accidents (Black Sites) in Manyar Gresik District?

2. How is the graphic presentation based on the Geographic Information System to illustrate areas that are prone to traffic accidents (Black Site) on the Manyar Gresik District road section?

\section{Literature Review}

\subsection{Traffic Accidents}

A traffic accident is an unexpected and unintentional road event involving a vehicle with or without other road users resulting in human casualties or property loss (PP RI No. 43 of 1993 concerning Infrastructure and Traffic). Criteria for traffic accident victims according to PP RI No. 43 of 1993 concerning Infrastructure and Traffic include [3]:

1. Died is a victim who is confirmed dead as a result of a traffic accident within a maximum of 30 (thirty) days after the incident.

2. Severe injuries are victims who have sustained permanent disability or have to be treated for more than 30 (thirty) days since the accident occurred. The meaning of permanent disability: if something is lost or not used at all and can not heal/recover forever.

3. Minor injuries are victims not included in points 1 and 2 above. 


\subsection{Road}

According to RI Law No. 38 of 2004 article 1 paragraph (4), road are land transportation infrastructure that covers all parts of the road, including complementary buildings and equipment intended for traffic, which are on the surface of land and/or water, and above the water surface, except for roads trains, lorries and cable roads.

\subsection{Accident Prone Areas}

Traffic accident-prone areas are areas that have a high number of traffic accidents, high risks, and accidents on a road [4].

The methods used to calculate accident rates are as follows [5]:

1. To calculate the number of traffic accidents using the EAN (Equivalent Accident Number) method, it is calculated by adding up the incidence of accidents in every 1 kilometer of road length then multiplied by the weight value according to the level of severity [3]. EAN formula:

$\mathrm{EAN}=12 \mathrm{MD}+6 \mathrm{LB}+3 \mathrm{LR}$

Where:

$$
\begin{array}{ll}
\text { MD } & =\text { Die } \\
\text { LB } & =\text { Wound Weight } \\
\text { LR } & =\text { Wound Light }
\end{array}
$$

2. To calculate each accident-prone areas using the UCL (Upper Control Limit) method, it is determined by the following equation: $\mathbf{U C L}=\lambda+\psi \mathrm{x} \sqrt{ }([(\lambda / \mathrm{m})+((0.829) / \mathrm{m})+(1 / 2 \mathrm{xm})])$

Where:

$$
\begin{array}{ll}
\lambda & =\text { Average EAN accident rate } \\
\psi & =\text { Probability factor }=2,576 \\
\mathrm{~m} & =\text { Number Reviewing road accident }(\text { EAN) }
\end{array}
$$

3. To determine the location of traffic accident-prone areas, it is carried out based on the number of accidents in every 1 kilometer of road that has an EAN weight value that exceeds the limit calculated by the BKA method (Upper Control Limit) with the following:

$$
\mathbf{B K A}=\mathbf{C}+\mathbf{3} \sqrt{\mathbf{C}}
$$

Where :

$$
\mathrm{C}=\text { Average EAN accident rate }
$$

\subsection{Geographical Information System}

Geographical Information System (GIS) or better known as Geographical Information System (GIS) is defined as a tool/media for entering, storing, retrieving, manipulating, analyzing, and displaying Geographical data (geospatial data) which is useful for supporting the process. decision-making planning and management of natural resources, environment, transportation, urban issues, and administrative [6]. Quantum GIS is one of the open-source GIS software. Quantum GIS was developed by a community incorporated in qqis.org, spearheaded by Gary Sherman. Quantum GIS can be used to produce maps in shapefile (.shp) format. Quantum GIS has other advantages, namely because it is open and community-based, Quantum GIS users are allowed to participate in developing various existing weaknesses so that Quantum GIS will continue to be a complete software [7].

\section{Method}

\subsection{Research Location}

This research will be conducted on collector roads in Manyar Gresik District which includes Jl. Raya Sembayat, J1 Raya Manyar, J1 Raya Sukomulyo, Jl Raya Roomo.

\subsection{Data Processing}

\begin{tabular}{|c|c|c|c|c|c|c|}
\hline \multirow{2}{*}{ No } & \multirow{2}{*}{ Street } & \multicolumn{4}{|c|}{ Year } & \multirow{2}{*}{ amount } \\
\hline & & 2016 & 2017 & 2018 & 2019 & \\
\hline 1 & Jl. Raya Roomo (KM 2) & 5 & 7 & 5 & 6 & 23 \\
\hline 2 & J1. Raya Roomo (KM 3) & 4 & 6 & 7 & 4 & 21 \\
\hline 3 & Jl. Raya Roomo (KM 4) & 3 & 8 & 6 & 7 & 24 \\
\hline 4 & Jl. Raya Sukomulyo (KM 5) & 5 & 8 & 8 & 7 & 28 \\
\hline 5 & Jl. Raya Sukomulyo (KM 6) & 4 & 11 & 8 & 9 & 32 \\
\hline 6 & J1. Raya Manyar (KM 7) & 8 & 10 & 14 & 8 & 40 \\
\hline 7 & J1. Raya Manyar (KM 8) & 10 & 12 & 12 & 8 & 42 \\
\hline 8 & J1. Raya Manyar (KM 9) & 8 & 16 & 10 & 7 & 41 \\
\hline 9 & J1. Raya Manyar (KM 10) & 21 & 28 & 26 & 17 & 92 \\
\hline
\end{tabular}

The data processing and analysis process is carried out based on the data on the number and condition of traffic accident victims in the Manyar Gresik sub-district in 2016-2019, which were obtained from the Gresik Police Traffic Unit. The data were analyzed using the EAN method to obtain the number of accidents per kilometer. The BKA method and the UCL method are used to determine accident-prone areas, then the data is entered into the QGIS software to obtain a more accurate accident-prone area map.

\section{Results and Discussion}

\subsection{Number of Traffic Accidents}

Table 1.Number of Traffic Accidents 


\begin{tabular}{lllllll}
\hline 10 & J1. Raya Sembayat (KM 11) & 7 & 8 & 9 & 7 & 31 \\
11 & Jl. Raya Sembayat (KM 12) & 8 & 9 & 8 & 8 & 33 \\
12 & Jl. Raya Sembayat (KM 13) & 7 & 7 & 7 & 6 & 27 \\
13 & Jl. Raya Sembayat (KM 14) & 6 & 7 & 8 & 8 & 29 \\
\hline
\end{tabular}

From the table above it can be seen that the highest number of accidents from 2016-2019 is on Jl. Raya Manyar (KM 10) of 92.

\subsection{Determine Accident Prone Areas}

The calculation of the number of accidents on collector roads in Manyar sub-district, district. Gresik is made in tabular form and also uses QGIS to display accident-prone locations as follows:

\subsubsection{Analysis of the EAN Accident Rate (Equivalent Accident Number)}

To determine accident-prone areas, you can use the EAN (Equivalent Accident Number) by adding up the incidents of accidents for every 1 kilometer of road length then multiplied by the value of death weight multiplied by 12 , serious injuries multiplied by 6 , minor injuries multiplied by 3 and vehicle damage multiplied by 1 . The following is the EAN calculation at KM 7:

Die

$: 6 \times 12=72$

Severe injuries

$.3 \times 6$

$=18$

Minor injuries

Vehicle Damage

$: 31 \times 3$

$=18$
$=93$

$: 42 \times 1$

$=42$

EAN Amount

$: 72+18+93+42=225$

\subsubsection{Limit Upper Control}

As an example of calculating the control limit in the upper control limit method, kilometer 2 is taken. From these kilometers, the total value of the EAN accident number is 433 for 3 road segments, so the average value (C) can be calculated as follows:

$$
\begin{aligned}
& \mathrm{C}=\frac{\Sigma E A N}{\text { Jumlah segmen }} \\
& \mathrm{C}=\frac{433}{3}=144.33
\end{aligned}
$$

With a $\mathrm{C}$ value of 144.33 , the BKA value can be calculated as follows:

$$
\mathrm{BKA}=\mathrm{C}+3 \sqrt{\mathrm{C}}=144.33+3 \sqrt{144.33}=180
$$

\subsubsection{UCL (Upper Control Limit)}

At kilometer 2 the total number of EAN accidents is 433 in 3 road segments. Then the average value ( $\lambda$ ) and the UCL value can be calculated as follows:

$\Lambda=433 / 3=144.33$

Probability factor $(\psi) \quad=2.576$

Value of $\mathrm{m}(\mathrm{EAN}) \quad=144$

Then the UCL value:

$$
\begin{aligned}
& \mathbf{U C L}=\lambda+\psi \times \sqrt{ }([(\lambda / \mathrm{m})+((0.829) / \mathrm{m})+(1 / 2 \times \mathrm{m})]) \\
& \mathrm{UCL}= 144.33+2.576 \times \sqrt{\left(\left(\frac{144,33}{144}\right)+\left(\left(\frac{0,829}{144}\right)\right)+(0,5 \times 144,33)\right)} \\
&= 166.34
\end{aligned}
$$

\subsubsection{Prone Areas Accident}

Table 2. Traffic Accident Prone Areas based on BKA and UCL Value.

\begin{tabular}{clcccl}
\hline \multirow{2}{*}{ No } & \multicolumn{1}{c}{ STA } & VALUE & BKA & UCL & \multirow{2}{*}{ EAN } \\
& VALUE & VALUE & \\
\hline 1 & Jl. Raya Roomo (KM 2) & 144 & 180 & 166.34 & Not Accident Prone \\
2 & Jl. Raya Roomo (KM 3) & 122 & 180 & 164.64 & Not Accident Prone \\
3 & Jl. Raya Roomo (KM 4) & 167 & 180 & 168 & Not Accident Prone \\
4 & Jl. Raya Sukomulyo (KM 5) & 168 & 224.1 & 207.26 & Not Accident Prone \\
5 & Jl. Raya Sukomulyo (KM 6) & 199 & 224.1 & 209.3 & Not Accident Prone \\
6 & Jl. Raya Manyar (KM 7) & 225 & 384 & 357 & Not Accident Prone \\
7 & Jl. Raya Manyar (KM 8) & 239 & 384 & 357,8 & Not Accident Prone \\
8 & Jl. Raya Manyar (KM 9) & 250 & 384 & 358.45 & Not Accident Prone \\
9 & Jl. Raya Manyar (KM 10) & 604 & 384 & 374.3 & Accident Prone \\
10 & Jl. Raya Sembayat (KM 11) & 194 & 219 & 204.24 & Not Accident Prone \\
11 & Jl. Raya Sembayat (KM 12) & 185 & 219 & 203.65 & Not Accident Prone \\
12 & Jl. Raya Sembayat (KM 13) & 167 & 219 & 202.44 & Not Accident Prone \\
13 & Jl. Raya Sembayat (KM 14) & 169 & 219 & 202.57 & Not Accident Prone
\end{tabular}




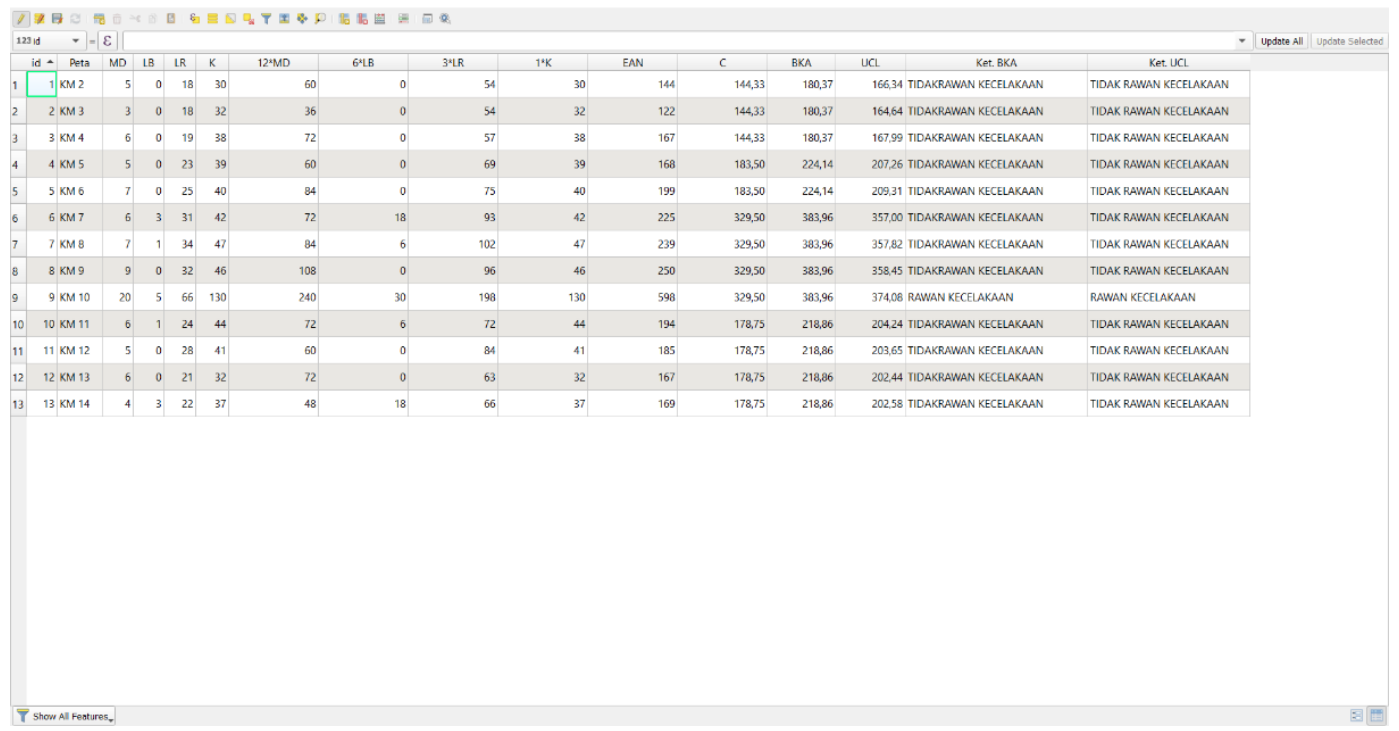

Fig 1. Attribute Table Information on Accident Prone Areas in QGIS

From the table above it can be concluded from the analysis of the EAN calculation with the BKA and UCL values where of the 13 cement there is 1 segment which is an accident-prone area, namely on Jl. Raya Manyar KM 10. At that point, the accident rate is very high due to the lack of awareness of motorists who often violate. The following are the existing conditions at an accident-prone point:

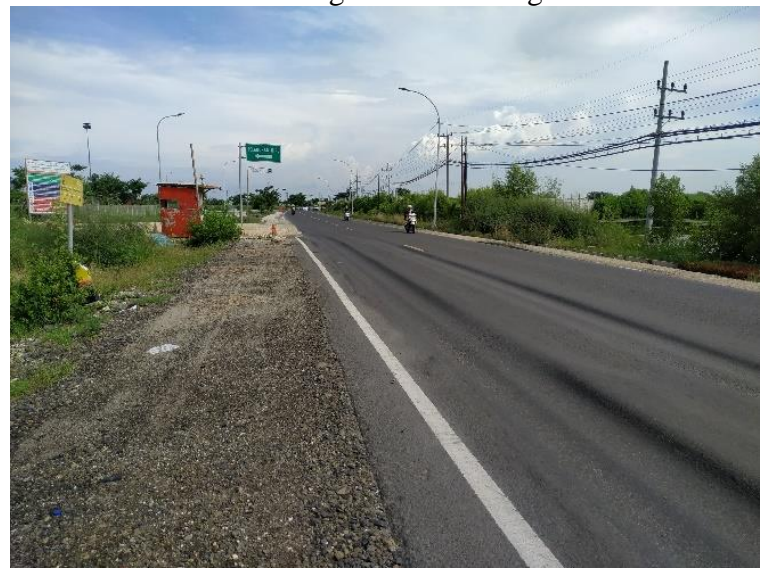

Fig 2. Existing Condition Kilometer 10

$$
\text { Jalur }
$$

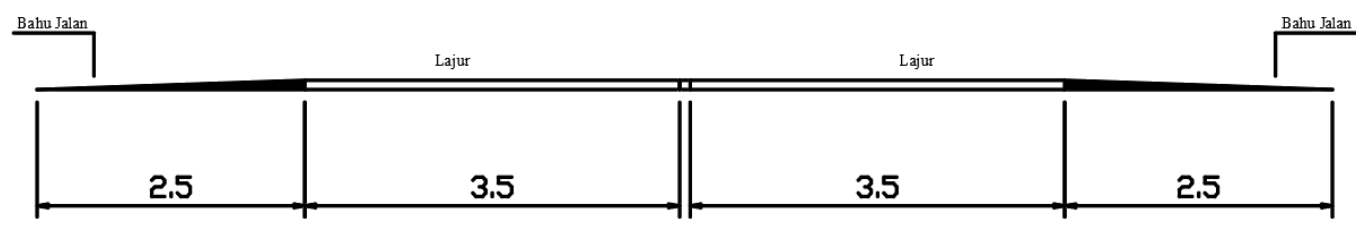

Fig 3. Street Pieces Kilometer 10

Furthermore, the results of the analysis from the table above are further analyzed using QGIS to categorize which areas are accident-prone and non-accident-prone areas by mapping based on the color of the road lines. The following is the result of the mapping of accident-prone areas based on the BKA and UCL (Upper Control Limit) methods: 


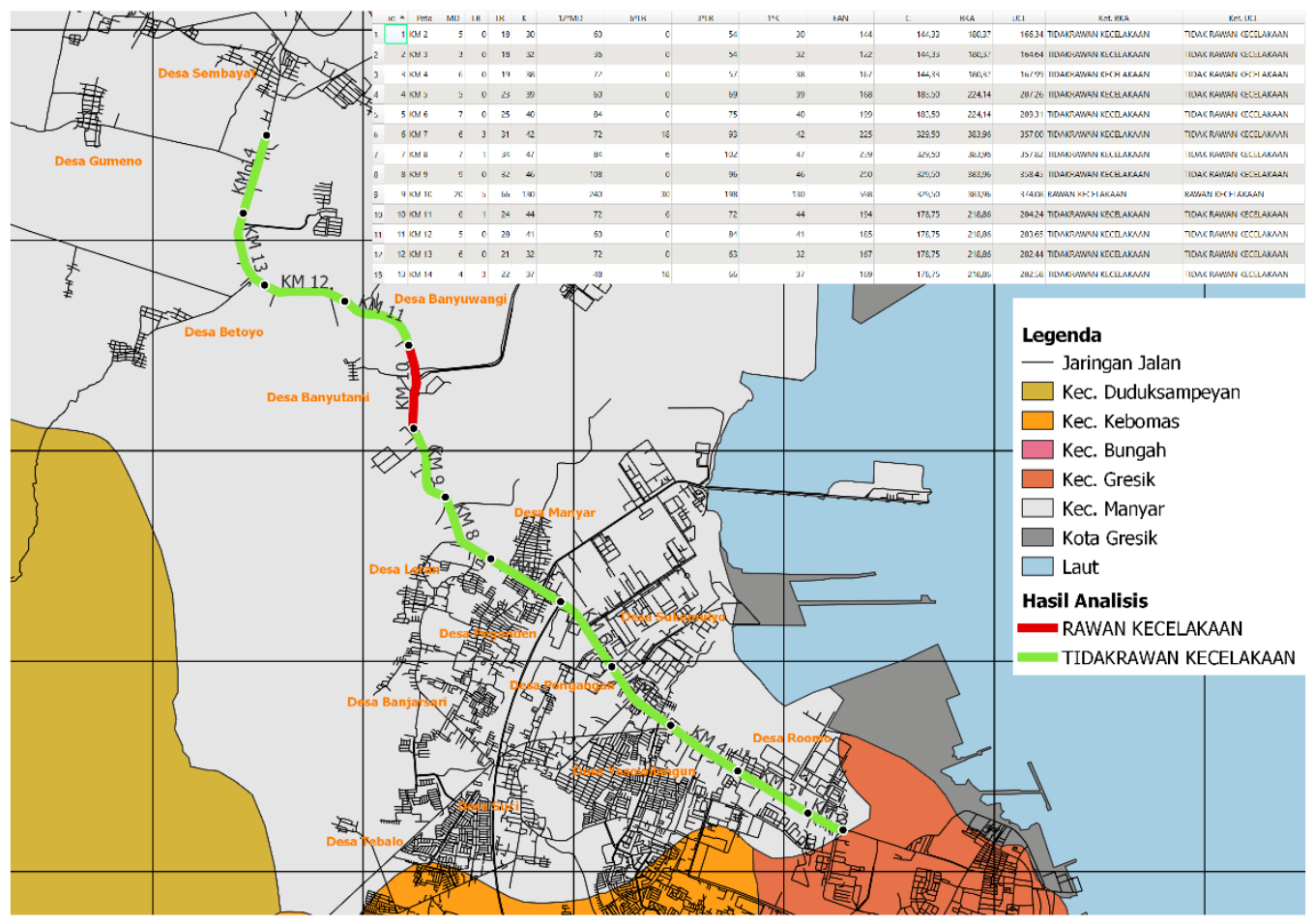

Fig 4. Mapping and Analysis Results

\section{Conclusion}

Based on the results of the above analysis it can be concluded as follows:

1. From the results of the analysis and secondary data obtained from the Satlantas Polres Gresik that on the roads in Manyar Gresik District, the most common types of accidents that occur are Front to Front accidents.

2. The number of accidents that occurred from 2016 - 2019 on roads in Manyar Gresik District was 285 incidents consisting of 58 incidents in 2016, 89 incidents in 2017, 76 incidents in 2018, and 62 incidents in 2019. Of the number of incidents accidents in 2016 - 2019 totaling 285 with 446 victims and involving 598 vehicles. Where the incident involved several casualties, including 89 victims who died, 14 were seriously injured and 361 slightly injured.

3. From the results of the analysis of the number of accidents using the EAN (Equivalent Accident Number) method, it is found that the road segment that has the highest accident rate is Jl Raya Manyar (Kilometer 10) with a value of 604.

4. From the results of the analysis, the accident-prone areas on the road in Manyar Gresik District are Jl. Raya Manyar (kilometer 10) with an EAN value of 604 exceeding the BKA value of 384 and a UCL value of 374.

\section{References}

[1] M. A. Spirito, "On the accuracy of cellular mobile station location estimation," IEEE Trans. Veh. Technol., 2001, doi: $10.1109 / 25.933304$.

[2] X. Xu, L. Ding, H. Luo, and L. Ma, "From Building Information Modeling to City Information Modeling," J. Inf. Technol. Constr., 2014.

[3] R. A. A. Soemitro, "Accident analysis assessment to the accident influence factors on traffic safety improvement," in Proceedings of the Eastern Asia Society for Transportation Studies, 2005, vol. 5, pp. 2091-2105.

[4] S. P. Warpani, Pengelolaan lalu lintas dan angkutan jalan. Penerbit ITB, 2002.

[5] P. Pertiwi, Y. Nurhantari, and S. Budihardjo, "Hazard identification, risk assesment and risk control serta penerapan risk mapping pada rumah sakit hewan Prof. Soeparwi Universitas Gadjah Mada," Ber. Kedokt. Masy., 2019, doi: 10.22146/bkm.42376.

[6] P. A. Burrough, "Principles of geographical," Inf. Syst. L. Resour. assessment. Clarendon Press. Oxford, 1986.

[7] T. A. Fitri and M. N. Arsyad, "Rancangan Aplikasi Pelayanan Kesehatan Berbasis Geographic Information System (GIS) Versi Android di Kota Pekanbaru," JST (Jurnal Sains Ter., 2018, doi: 10.32487/jst.v3i2.256. 